$$
\text { Wri- KS } 2^{K-1849}
$$

\title{
MASS SPECTROMETER VACUUM-LOCK CARRIAGES COATED WITH TEFLON-S
}

O. H. Howard

A. Langdon 


\section{DISCLAIMER}

This report was prepared as an account of work sponsored by an agency of the United States Government. Neither the United States Government nor any agency Thereof, nor any of their employees, makes any warranty, express or implied, or assumes any legal liability or responsibility for the accuracy, completeness, or usefulness of any information, apparatus, product, or process disclosed, or represents that its use would not infringe privately owned rights. Reference herein to any specific commercial product, process, or service by trade name, trademark, manufacturer, or otherwise does not necessarily constitute or imply its endorsement, recommendation, or favoring by the United States Government or any agency thereof. The views and opinions of authors expressed herein do not necessarily state or reflect those of the United States Government or any agency thereof. 


\section{DISCLAIMER}

Portions of this document may be illegible in electronic image products. Images are produced from the best available original document. 
Printed in the United States of America. Available from

National Technical Information Service

U.S. Department of Commerce

5285 Port Royal Road, Springfield, Virginia 22151

Price: Printed Copy \$4.00; Microfiche $\$ 0.95$

This report was prepared as an account of work sponsored by the United States Government. Neither the United States nor the United States Atomic Energy Commission, nor any of their employees, nor any of their contractors, subcontractors, or their employees, makes any warranty, express or implied, or assumes any legal liability or responsibility for the accuracy, completeness or usefulness of any information, apparatus, product or process disclosed, or represents that its use would not infringe privately owned rights. 


\section{MASS SPECTROMETER VACUUM-LOCK CARRIAGES} COATED WITH I'EFLON-S

O. H. Howard and A. Langdon

Isotopic Analysis Department Laboratory Division

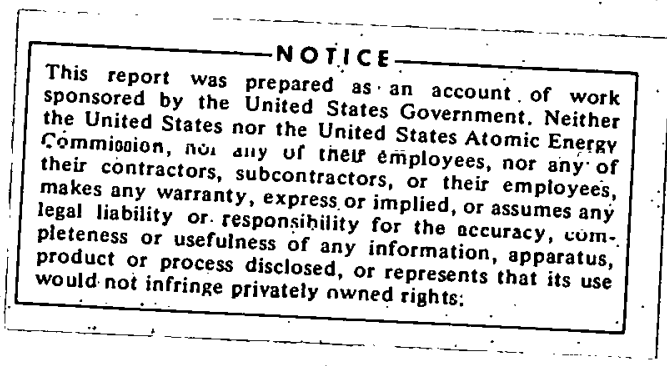

Oak Ridge Gaseous Diffusion Plant

Union Carbide Corporation

Oak Ridge, Terınessee

Prepared for the U. S. Atonic Energy Commission under U. S. Government Contract W-7405 eng 26 
ABSTRAC,T

Seizing of the metal-to-metal, piston-like carriages of a thermal ionization mass spectrometer vacuum lock was eliminated by replacing $0.0015 \mathrm{in}$. of the carriage surface with Teflon-S. The vacuum lock has been operated 1600 times in the 3.5 years since the carriages were coated. Both the plastic surface and the mass spectrometer vacuum remain satisfactory. 
CONTENTS

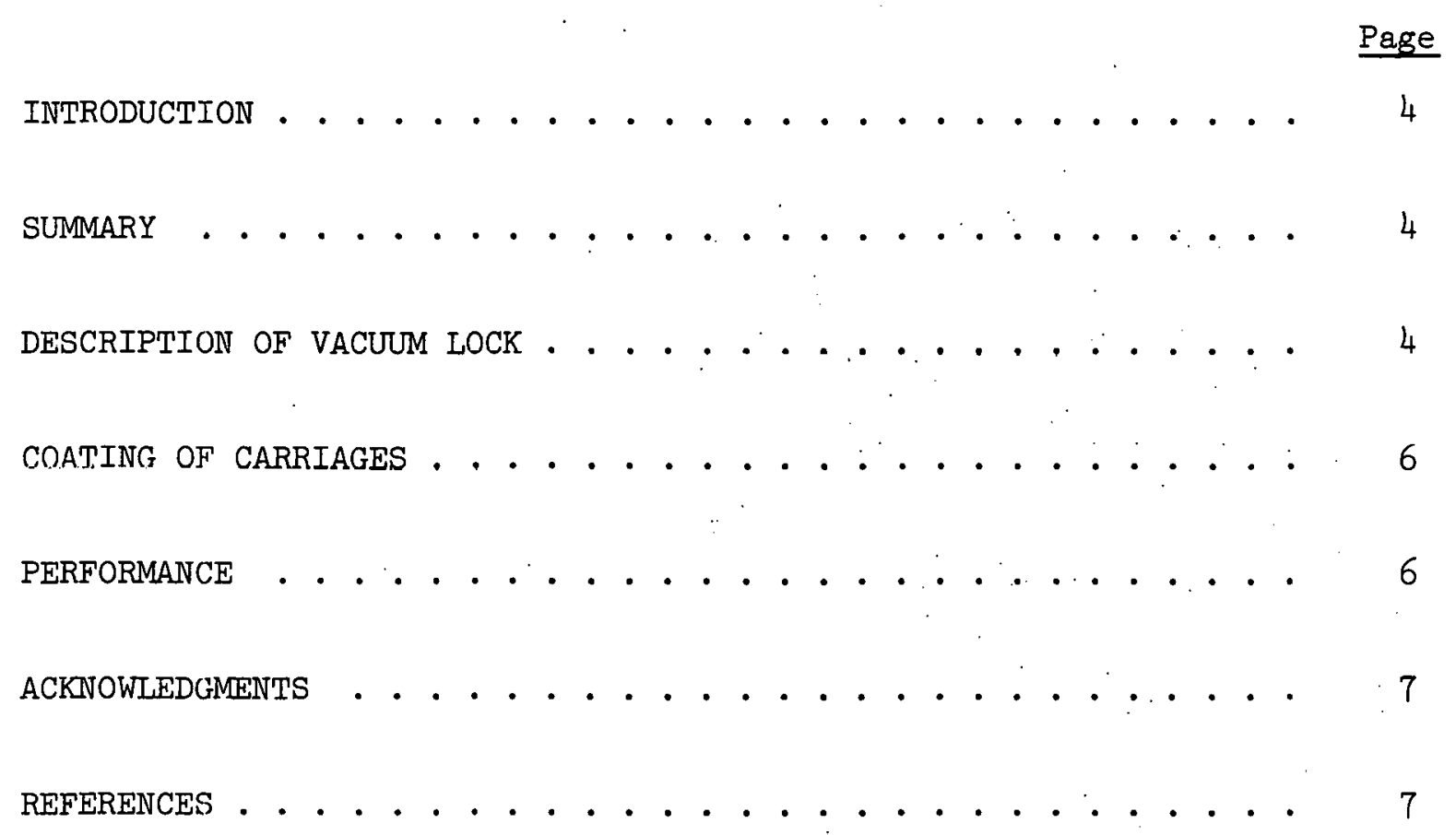




\section{INTRODUCTION}

A thermal ionization mass spectrometer is us;ed at the Oak Ridge Gaseous Diffusion Plant for the isotopic analysis of uranium as well as other elements. It is a $12-i n$. radius, $60^{\circ}$ magnetic instrument supplied by Nuclide Corporation as SU-1.1

A sliding-bar type vacuum $10 \mathrm{ck}^{2}$ enables changing samples without breaking vacuum. The original chromium plated stainless-steel, piston-like carriages of the vacuum lock were designed to slide inside a close-fitting stainless-steel cylinder without lubrication. The vacuum lock performed satisfactorily for 10 years before the sliding surfaces seized.

Return of the vacuum lock to the manufacturer for repair was considered. However, anticipated high cost, long downtime, and uncertainty of a permanent solution to the problem prompted coating of the carriages. With Teflon-S. ${ }^{3}$

\section{SUMMARY}

A metal-to-metal sliding-carriage vacuum lock, used to introduce samples into a thermal ionization mass spectrometer, became inoperable due to seizing of the contacting surfaces. The problem was solved by removing $0.0015 \mathrm{in}$. of metal. from the surfaces of the carriages and replacing it with Teflon-S. No deterioration of the plastic coating or of the mass spectrometer vacuum has been observed after 3.5 years and 1600 operations of the vacuum lock.

\section{DESCRIPTION OF VACUUM LOCK}

The vacuum l.ock (figure 1), fabricated of stainless steel, includes the ion-source chamber, two cylinders of nominal 3-in. ID extending from opposite sides of the chamber, and a source carriage and a blank carriage - which slide inside the cylinders with less than $0.0003-i n$. clearance. The source and blank carriages are 7 and 16 in. long, respectively.

Three circumferential recesses at intervals in the cylinders connect with pumps and provide differential pumping stages. The outer and middle stages are pumped by $350-$ and $100-\ell / \mathrm{min}$ mechanical pumps, and the inner 
DWG. NO. G-68-653
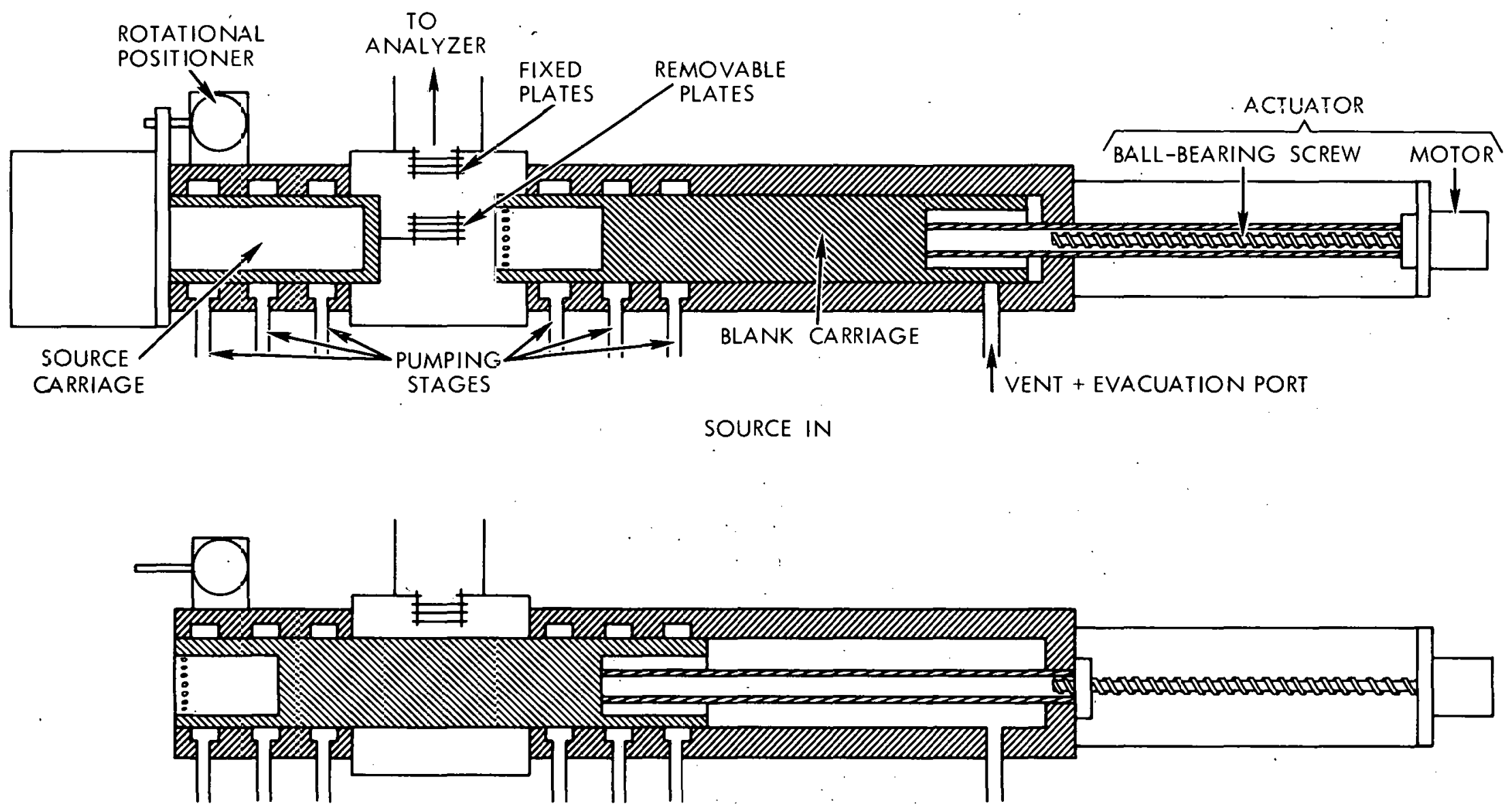

SOURCE OUT

Figure 1

MASS SPECTROMETER VACUUM LOCK 
stages are pumped by a $15-l / \mathrm{sec}$, water-cooled electronic pump. Teflon chevron gaskets at the outer ends of the cylinders retard atmospheric inleakage. (The actuator and rotational positioner, shown in figure 1 , were designed and fabricated at this flant. $)^{4}$

During analysis of a sample, the carriages are in the positions shown in the top portion of figure 1 . When the source carriage is removed to change the sample, the electrically driven blank carriage displaces it (bottom portion of figure 1), preventing loss of vacuum in the mass spectrometer. For reinsertion, the source carriage is manually forced past a Teflon chevron gasket into the first pumping stage as the blank carriage is withdrawn. Thereafter, the source carriage is driven by atmospheric pressure, as the blank carriage is withdrawn, until the source carriage is fully inserted.

\section{COATING OF CARRIAGES}

Mandrels were machined for mounting the carriages in a grinder. The carriages were ground until their diameters had been reduced 0.003 in. They were then vapor blasted, cleaned in acetone, and baked $15 \mathrm{~min}$ at $650^{\circ} \mathrm{F}$ to degas them. Next, the carriages were given three coats of Teflon-S, according to the manufacturer's instructions ${ }^{3}$, for a total film thickness of about 0.003 in. The Teflon-S liquid, consisting of "a special fluorocarbon resin and suitable modifiers dispersed in organic solvents" 3 , was applied with a manual spray gun. The first and second coats were baked $15 \mathrm{~min}$ at $300^{\circ} \mathrm{F}$, and the final coat was baked $15 \mathrm{~min}$ at $650^{\circ} \mathrm{F}$.

Finally, the coated carriages were reduced to the required carriage diameter by surface grinding. The thickness of the resulting Teflon-s film was 0.0015 in. as determined from the finished carriage diameter minus the precoating diameter.

\section{PERFORMANCE}

Using the vacuum lock with the coated carriages, the mass spectrometer source and analyzer pressures are $4 \times 10^{-7}$ and $2 \times 10^{-8}$ torr, respectively, during an analysis, one hour after a sample change. These pressures compare with $1 \times 10^{-7}$ and $1 \times 10^{-8}$ torr for the previous metal carriages during an analysis, one hour after a sample change. (All stated analysis pressures are with a liquid nitrogen coldfinger, not shown in figure 1 , in the source chamber.) The slightly higher pressures with the coated carriages are probably due to imperfect carriage diameter, which could be improved with additional sizing care.

The vacuum lock has been operated 1600 times during the 3.5 years since the carriages were coated, with no deterioration of spectrometer vacuum. The coating remains adherent and sound. Mishandling has caused a few minor blemishes on the source-carriage coating; however, these have not affected nerformance, 


\section{ACKNOWLEDGMENTS}

Grinding and coating of the vacuum lock carriages were under the directions of C. L. Eller and C. R. Barlow, respectively, of the Fabrication and Maintenance Division, Oak Ridge Gaseous Diffusion Plant.

\section{REFEREINCES}

1. Warren, V. L., and Horton, J. C., Uranium Isotope Measurements with a ModeZ SU-1 Surface Ionization Mass Spectrometer, Union Carbide Corporation, Nuclear Division, Oak Ridge Gaseous Diffusion Plant, March 22, 1962 (K-1463). UNCLASSIFIED.

2. "Vaculum Locks," Brochure No. 20, 1962, Nuclide Corporation, 642 East College Ave., State College, Pa.

3. "Teflon-S Non-Stick Finishes, 958-200 Series," Technical Information Report No. A-64509, February 1969, E. I. duPont de Nemours and Co. (Inc.), $308 \mathrm{E}$. Lancaster Ave., Wyrnewood, Pa.

4. Howard, Olin H., Langdon, Aubrey, and Taylor, Fred W., Vacuum-Lock Actuator and Ion-Source Positioner for a Surface Ionization Mass Spectrometer, Union Carbide Corporation, Nuclear Division, Oak Ridge Gaseous Diffusion Plant, Oak Ridge, Tennessee, August 4, 1969 $(\mathrm{K}-1776)$. UNCLASSIFIED. 
DISTRIBUTION

INTERNAL

1- 2. Administrative Offices Stief, S. S. Winkel, R. A.

24-25. Operations Division Barlow, C. R. Legeay, A. J.

3. Computing Technology Center Allen, C. L.

4. Engineering Division Patton, F. S.

5- 6. Fabrication \& Maint. Div. Krieg, E. H., Jr. Studinger, L. A.

26. Shift Operations \& Pollution Control Hartman; W. C.

27. Sommerfeid, K. W.

28. Technical Director Wilcox, W. J., Jr.

29-31. ORGDP Records Department (RC)

7. Gaseous Diffusion Dev. Div. Trammell, H. E.

32. U. S. Atomic Energy Commission Zachry, D. S.

8-12. Laboratory Division Barton, J. C. Howard, O. H. Langdon, A. Napolitan, D. S. Smith, L. A.

33. Goodyear Atomic Corporation Voss, F. S.

34. Paducah Plant Katzel, V. G.

13-21. Library Fraser, R. J. 35-37. Y-12 Plant Briscoe, 0. W. Burkhart, L. E.

22-23. Operations Analysis \& LRP Div. Griffin, J. D. Lang, D. M. Pasquier, I. P.

EXTERNAL

38-218. TID-4500 